\title{
EFEKTIVITAS EKSTRAK BABADOTAN (Ageratum conyzoides $L$.) TERHADAP TINGKAT KEMATIAN LARVA Spodoptera litura F.
}

\author{
EFFECTIVITY OF BABADOTAN EXTRACT (Ageratum conyzoides L.) TO MORTALITY OF \\ LARVAL Spodoptera litura $F$.
}

\author{
Sonja Verra Vinneke Lumowa*) \\ ") Program Studi Pendidikan Biologi FKIP Universitas Mulawarman Samarinda \\ JI. Muara Pahu, Kampus UNMUL, Samarinda, Telp.+62-541-743651, Fax. +62-541-743929 \\ Email: sonjalumowa@yahoo.co.id
}

\begin{abstract}
Effectivity of babadotan extract (Ageratum conyzoides L.) to mortality larval of Spodoptera litura F. had been conducted at the Laboratory of Wood Chemistry, Faculty of Forestry and the Laboratory of Biology Education, Faculty of Teacher Training and Education University of Samarinda Mulawarman from June to October 2010. The study aimed to determine the effectivity of the babadotan extract to mortality of larval S. litura (instarlV). Research activities were the preliminary test and advanced test. Preliminary test was the concentration of six treatments namely $0 \%, 0.001 \%, 0.01 \%, 0.1 \%, 1 \%$ and $10 \%$, while the advanced test consisted of four treatments viz the concentration of $0 \%, 5 \%, 10 \%$ and $20 \%$. The result showed that the concentration of $10 \%$ resulted death rate by $60 \%$ of test larvae in preliminary trials. Whereas, the treatment of advanced test with a concentration of $20 \%$ revealed that the death rate was $100 \%$ with the periode of mortality $26-60$ minutes.
\end{abstract}

Keywords: extract babadotan, Spodoptera litura larvae

\begin{abstract}
ABSTRAK
Penelitian efektivitas ekstrak babadotan (Ageratum conyzoides L.) terhadap tingkat kematian larva instar IV Spodoptera litura F. telah dilaksanakan di Laboratorium Kimia Kayu Fakultas Kehutanan, dan di Laboratorium Pendidikan Biologi Fakultas Keguruan dan IImu Pendidikan Universitas Mulawarman Samarinda 30 Juni 2010 sampai dengan 8 oktober 2010. Penelitian bertujuan untuk mengetahui efektivitas ekstrak babadotan ( $A$. conyzoides) terhadap tingkat kematian larva instar IV $S$. litura instar. Kegiatan penelitian terdiri dari uji pendahuluan dan uji lanjutan. Uji pendahuluan digunakan 6 perlakuan yaitu konsentrasi $0 \%, 0,001 \%, 0,01 \%, 0,1 \%, 1 \%$ dan 10\%; sedangkan uji lanjutan terdiri dari 4 perlakuan yaitu konsentrasi $0 \%, 5 \%, 10 \%$ dan $20 \%$. Hasil penelitian menunjukkan bahwa pada uji pendahuluan dengan perlakuan konsentrasi $10 \%$ menghasilkan tingkat kematian larva uji sebesar 60 $\%$; sedangkan pada uji lanjutan dengan perlakuan konsentrasi $20 \%$ menghasilkan tingkat kematian larva uji sebesar $100 \%$ dengan lama kematian larva uji 26-60 menit.
\end{abstract}

Kata kunci: ekstrak babadotan, larva Spodoptera litura

Eugenia Volume 17 No. 3 Desember 2011 


\section{PENDAHULUAN}

Serangga mempunyai peranan penting dalam kehidupan manusia. Manusia mendapatkan banyak manfaat dari kehadiran serangga. Beberapa jenis serangga bermanfaat sebagai pollinator atau serangga penyerbuk, penghasil madu dan sutera. Sebaliknya banyak jenis serangga yang dapat merugikan manusia, seperti serangga perusak tanaman, serangga vektor baik yang menyebabkan penyakit pada tanaman maupun pada manusia (Jumar, 1997).

Setiap jenis tanaman pertanian tidak akan pernah terhindar dari gangguan hama dan penyakit. Serangga hama dapat menyebabkan tunas tanaman meranggas, daunnya berlubang atau semua daunnya habis hingga tersisa tulang daun atau serat daunnya saja. Kondisi seperti ini dapat menyebabkan terjadinya penurunan kuantitas maupun kualitas hasil tanaman pertanian.

Usaha pengendalian hama yang dilakukan oleh petani di Indonesia masih sering menggunakan insektisida sintetis sehingga menyebabkan efek samping yang serius seperti terjadinya pencemaran udara, tanah dan air, matinya organisme non sasaran (musuh alami), dan terjadinya resurjensi hama (Pandit, 2006).

Sejak berdirinya Pusat IImu Pengetahuan Botani oleh Belanda pada tahun 1888, banyak dilakukan penelitian tentang tanaman beracun di Indonesia dan sejak tahun 1950-an telah dilakukan penelitian tentang pemanfaatan tanaman seperti tanaman tuba, bunga krisan liar sebagai pestisida nabati (Novizan, 2002). Hamid \& Nuryani (1992) mencatat di Indonesia terdapat 50 famili tumbuhan penghasil racun. Famili tumbuhan yang dianggap merupakan sumber potensial insektisida nabati adalah Meliaceae, Annonaceae, Asteraceae, Piperaceae dan Rutaceae (Arnason et.al., 1993; Isman, 1995). Seperti halnya tanaman beracun lainnya, babadotan juga memiliki kemampuan sebagai insektisida nabati (racun serangga), karena dalam babadotan terkandung senyawa penting atau senyawa metabolit yang bersifat sebagai insektisida seperti alkaloid, flavonoid, kumarin, saponin, polifenol, dan minyak atsiri (Kardinan, 2001).

S. litura merupakan serangga hama yang menyerang atau memakan tanaman pada bagian daun sehingga meninggalkan lubang (Sudarmo, 2000). larva biasanya menyerang tanaman padi, kubis, sawi, kacang-kacangan, kentang, cabai, bawang merah dan tanaman lainnya (Soemadi, 2003 dan Pracaya, 2005). Kemampuan merusak serangga hama ini tergantung pada perkembangan stadianya (Harahap, 2005). Larva instar I ulat memakan epidermis daun hingga menyisakan serat-serat daun. Larva instar II dan III memakan helaian daun dengan meninggalkan tulang-tulang daunnya. Sedangkan larva instar IV dan V dapat memakan seluruh daun sampai ketulang-tulang daunnya sehingga akan sangat mengganggu pertumbuhan tanaman yang diserangnya.

Berbagai cara dilakukan untuk mengendalikan hama $S$. litura, diantaranya memanfaatkan tanaman babadotan dengan cara membuat ekstrak dari tanaman tersebut, dan telah diketahui bahwa pengendalian dengan cara ini ramah lingkungan karena tidak mengandung bahan kimia yang berbahaya yang dapat merusak komponen tanah maupun organisme yang ada di sekitar tanaman.

Penelitian bertujuan untuk mengetahui efektivitas ekstrak babadotan ( $A$. conyzoides) terhadap tingkat kematian larva $S$. litura instar IV.

\section{METODE PENELITIAN}

Penelitian ini dilaksanakan sejak 30 Juni 2010 sampai dengan 8 oktober 2010. Penelitian dilaksanakan pada areal pertanian Lempake Desa Joyo Mulyo, kemudian dilanjutkan di Laboratorium Kimia Kayu Fakultas Kehutanan untuk ekstrasi dan Laboratorium Biologi untuk pengenceran dan pengujian ekstrak.

\section{Prosedur Kerja \\ Rearing Larva S. litura}

Larva $S$. litura diambil pada lahan pertainan (lokasi Desa Joyo Mulyo kecamatan Lempake) kemudian dipelihara di dalam stoples-stoples (berdiameter $\pm 10-25 \mathrm{~cm}$ ) yang sudah disediakan. Tiap-tiap toples ditutup dengan menggunakan kain sifon. 
Pakan untuk pemeliharaan larva adalah daun sawi, pakan diganti setiap hari, pagi dan sore hari agar larva selalu mendapatkan pakan yang segar dan sebelumnya stoples-stoples tersebut dibersihkan terlebih dahulu. Masing-masing stoples diberi 5 lembar daun sawi (ukuran hampir sama besar).

Setelah larva mencapai stadia pupa, diletakkan pada wadah yang diberi alas kapas lembab dan dipelihara di dalam kotak pemeliharaan serangga. Setelah menjadi imago dibiarkan tetap di dalam kotak pemeliharaan untuk berkopulasi. Imago diberi larutan madu sebagai makanannya. Telur-telur yang diperoleh dari hasil rearing dipelihara sampai menetas dan menjadi larva dan dipelihara terus sampai mencapai instar IV yang digunakan sebagai larva uji. Larva diberi lembar daun sawi yang diganti setiap harinya. Pengamatan dilakukan setiap hari untuk mengetahui lama hidup masingmasing stadia.

\section{Pembuatan Ekstrak Babadotan}

Babadotan dibersihkan kemudian dipotong dan dikeringkan dikeringkan selama lebih kurang 10 hari, kemudian ditumbuk dan ditimbang berat kering $0.5 \mathrm{~kg}$. Bubuk babotan dilakukan maserasi dengan menggunakan pelarut etanol $90 \%$ di dalam gelas kimia selama 3 hari sekali diaduk dengan menggunakan sendok kayu.

Setelah 3 hari hasil rendaman tersebut disaring dengan menggunakan kertas saring dan corong ke dalam gelas kimia. Dilakukan maserasi kembali dengan menggunakan larutan etanol $96 \%$ dari sisa ampas maserasi sebelumnya hingga ekstraksi yang dihasilkan jernih.

Kemudian hasil ekstraksi tersebut dilakukan pemekatan larutan dengan menggunakan rotary evaporator. Ekstrak yang pekat dimasukkan kembali ke dalam oven vakum hingga wujudnya menjadi agak kental seperti menyerupai pasta.

\section{Pengujian Ekstrak Babadotan Uji Pendahuluan}

Uji pendahuluan digunakan untuk menentukan konsentrasi ambang atas dan konsentrasi ambang bawah, dimana pada uji pendahuluan ini menggunakan 6 perlakuan yaitu konsentrasi $0 \%$ (kontrol); $0,001 \% ; 0,01 \% ; 0,1 \% ; 1 \%$ dan $10 \%$. Masing-masing perlakuan diberi larva uji sebanyak 5 ekor, sehingga jumlah sampel larva uji adalah sebanyak 30 ekor. Larva uji diberi pakan berupa daun sawi yang telah disemprot dengan ekstrak larutan babadotan berdasarkan masing-masing konsentrasi, kemudian diamati selama 24 jam.

Penentuan ambang atas dan bawah konsentrasi ekstrak babadotan mengikuti rumus :

$$
\log \frac{N}{n}=k \log \frac{a}{n}
$$

$\mathrm{N}=$ Konsentrasi ambang atas

$\mathrm{n}=$ konsentrasi ambang bawah

$\mathrm{k}=$ jumlah konsentrasi yang akan diuji

$\mathrm{a}=$ konsentrasi terkecil dalam deretan yang akan ditentukan setelah $\mathrm{n}$.

Dengan menggunakan rumus tersebut maka dapat ditentukan nilai konsentrasi a,b,c,d, dan e dengan rumus:

$$
\frac{\mathrm{a}}{\mathrm{n}}=\frac{\mathrm{b}}{\mathrm{a}}=\frac{\mathrm{c}}{\mathrm{b}}=\frac{\mathrm{d}}{\mathrm{c}}=-=\frac{\mathrm{E}}{\mathrm{a}}
$$

Berdasarkan rumus di atas dosis yang digunakan $0,001 \% ; 0,01 \% ; 0,1 \% ; 1 \% ; 10 \%$ dan kontrol (tidak diberi ekstrak) maka terdapat 6 perlakuan.

\section{Uji Lanjutan}

Uji lanjutan dilakukan berdasarkan hasil uji pendahuluan untuk menetapkan ambang lethal konsentrasi yang akan digunakan. Larva instar IV sebanyak 10 ekor masing-masing dimasukkan ke dalam stoples berdiameter $25 \mathrm{~cm}$. Daun sawi masing-masing disemprot dengan ekstrak babadotan berdasarkan tingkat perlakuan/konsentrasi yaitu $5 \%, 10 \%$, dan $20 \%$ (2,5 gr dalam $50 \mathrm{ml}$ aquades untuk konsentrasi $5 \%$; $5 \mathrm{gr}$ dalam $50 \mathrm{ml}$ aquades untuk konsentrasi $10 \%$; dan $10 \mathrm{gr}$ dalam $50 \mathrm{ml}$ aquades untuk konsentrasi 20\%). Penyemprotan dilakukan masing-masing sebanyak 8 kali semprotan pada daun sawi sebagai makanan larva uji. Pengamatan dilakukan selama 24 jam dengan mencatat jumlah larva uji yang mati dan waktu kematian larva setelah aplikasi ekstrak babadotan.

\section{Pengamatan}

Hal-hal yang diamati dalam penelitian ini adalah lama hidup $S$. litura, tingkat kematian larva uji (uji pendahuluan dan uji lanjutan). 


\section{HASIL DAN PEMBAHASAN}

\section{Lama Hidup S. litura}

Hasil pengamatan pada rearing $S$. litura di laboratorium ternyata lama hidup masing-masing stadia perkembangan $S$. litura bervariasi seperti terlihat pada Tabel 1. Berdasarkan Tabel 1 ternyata total lama hidup $S$. litura di laboratorium mencapai 41 hari yang terdiri dari stadium telur 3 hari dimulai sejak peletakan telur sampai menetas menjadi larva, stadium larva terdiri dari 5 instar mencapai 20 hari untuk berubah menjadi prapupa, stadium prapupa mencapai waktu 2 hari untuk menjadi pupa, stadium pupa mencapai 9 hari, dan lama hidup imago mencapai 7 hari.

Menurut Ardiansyah (2007) sekor imago betina dapat meletakkan 2000-3000 telur. Ulat berkepompong dalam tanah, membentuk pupa tanpa rumah pupa (kokon), berwarna coklat kemerahan dengan panjang sekitar $1,6 \mathrm{~cm}$. Siklus hidup berkisar antara 30-60 hari (lama stadium telur 2-4 hari, larva yang terdiri dari 5 instar : 20-46 hari, pupa: 811 hari). Selanjutnya Kalshoven (1981) menyatakan bahwa $S$. litura diklasifikasikan dalam ordo Lepidoptera dan famili Noctuidae adalah serangga hama penting pada beberapa tanaman pertanian. Perkembangan $S$. litura dari stdium telur sampai imago mencapai 30- 36 hari.

\section{Pengaruh Ekstrak Tanaman Babadotan Uji Pendahuluan}

Hasil pengamatan menunjukkan bahwa pada uji pendahuluan hanya perlakuan dosis $10 \%$ yang dapat membunuh larva uji dengan tingkat kematian mencapai $60 \%$ seperti terlihat pada Tabel 2.

Pada perlakuan dengan konsentrasi $0-1 \%$ tidak ditemukan adanya kematian larva. Hal ini diduga karena rendahnya residu senyawa aktif yang tertinggal pada daun perlakuan setelah penyemprotan. Rendahnya deposit senyawa aktif dapat disebabkan karena terjadinya degradasi bahan aktif oleh faktor lingkungan terutama sinar matahari dan suhu. Scott et.al. $(2003,2004)$ melaporkan penurunan residu senyawa dapat disebabkan sinar mata- hari. Lebih lanjut, Cabizza et al. (2004) melaporkan bahwa senyawa tefrosin dan deguelin dapat didegradasi oleh cahaya matahari. Prijono (1999) mengemukakan bahwa beberapa kekurangan insektisida botani antara lain persistensinya yang rendah, sehingga pada tingkat populasi hama yang tinggi untuk mencapai keefektifan pengendalian yang maksimum diperlukan aplikasi yang berulang-ulang.

\section{Uji Lanjutan}

Pada uji lanjutan menggunakan 4 perlakuan yaitu konsentrasi $0 \%$ (kontrol), 5\%, 10\% dan $20 \%$. Hasil pengamatan menunjukkan bahwa pada perlakuan konsentrasi $5 \%$ mortalitas larva $30 \%$, perlakuan konsentrasi $10 \%$ menghasilkan mortalitas sebanyak $70 \%$, sedangkan pada konsentrasi $20 \%$ mortalitas larva uji mencapai $100 \%$.

Hasil penelitian menunjukkan bahwa ekstrak babadotan dapat digunakan sebagai insektisida botani untuk mengendalikan lara $S$. litura. Pada dosis perlakuan $20 \%$ dapat menyebabkan tingkat mortalitas sebesar $100 \%$ dengan waktu lebih kecil dari 1 jam. Gejala pada sampel larva uji yang mati setelah perlakuan adalah tubuh larva uji mengecil pada bagian abdomennya dan mengeluarkan bau yang tidak sedap.

Babadotan merupakan tumbuhan merupakan tumbuhan yang berbentuk herba yang banyak tumbuh di kawasan hutan sampai ketinggian 2.100 meter dpl. Daun Babadotan mengandung senyawa alkaloid dan flafanoid.

Menurut Dinata (2007) flafonoid dapat dimanfaatkan sebagai bahan aktif dalam pembuatan insektisida nabati. Sedangkan alkaloid menurut Suryani (1991) dalam Sanyoto (2003), merupakan senyawa pahit dan beracun dapat menyebabkan rasa pusing dan tidak mau makan daun sawi disebabkan rasanya yang pahit dan akhirnya mati. Lebih lanjut Samsudin (2008) menyatakan bahwa kandungan aktif tanaman babadotan adalah saponin, flavanoid dan polifenol mampu mencegah hama mendekati tanaman (penolak) dan mampu menghambat pertumbuhan larva menjadi pupa. 
Tabel 1. Lama Hidup S. litura Di Laboratorium

(Table 1. Life Cycle of S. litura in the Laboratory)

\begin{tabular}{ccc}
\hline No. & Fase Perkembangan & Lama hidup (hari) \\
\hline 1. & Telur & 3 Hari \\
2. & Larva Instar 1 & 2 Hari \\
& Larva Instar 2 & 3 Hari \\
& Larva Instar 3 & 4 Hari \\
& Larva Instar 4 & 5 Hari \\
Larva Instar 5 & 6 Hari \\
& Prapupa & 2 Hari \\
& Pupa & 9 Hari \\
& Imago & 7 Hari \\
\hline
\end{tabular}

Tabel 2. Mortalitas Larva pada Uji Pendahuluan

(Table 2. Larval Mortality in the Introduction Test)

\begin{tabular}{cccc}
\hline $\begin{array}{c}\text { Perlakuan/konsentrasi } \\
\text { Ekstrak Babadotan (\%) }\end{array}$ & $\begin{array}{c}\text { Jumlah Sampel Larva } \\
\text { Uji }\end{array}$ & $\begin{array}{c}\text { Jumlah Larva yang } \\
\text { Mati (24 jam) }\end{array}$ & $\begin{array}{c}\text { Persentase } \\
\text { Kematian (\%) }\end{array}$ \\
\hline 0 & 5 & 0 & 0 \\
0,001 & 5 & 0 & 0 \\
0,01 & 5 & 0 & 0 \\
0,1 & 5 & 0 & 0 \\
1 & 5 & 0 & 0 \\
10 & 5 & 3 & 60 \\
\hline
\end{tabular}

Tabel 3. Mortalitas Larva pada Uji Lanjutan

(Table 3. Larval Mortality at the Follow-Up Test)

\begin{tabular}{ccccc}
\hline $\begin{array}{c}\text { Perlakuan/konsentrasi } \\
\text { ekstrak babadotan }(\%)\end{array}$ & $\begin{array}{c}\text { Jumlah sampel } \\
\text { larva uji }\end{array}$ & $\begin{array}{c}\text { Jumlah larva yang } \\
\text { mati }(24 \text { jam) }\end{array}$ & $\begin{array}{c}\text { Persentase } \\
\text { kematian }(\%)\end{array}$ & $\begin{array}{c}\text { Waktu kematian } \\
\text { (jam) }\end{array}$ \\
\hline 0 (kontrol) & 10 & 0 & 0 & 0 \\
5 & 10 & 3 & 30 & $4-12$ \\
10 & 10 & 7 & 70 & $4-19$ \\
20 & 10 & 10 & 100 & $<1$ \\
\hline
\end{tabular}

Pestisida nabati dapat mengendalikan serangan hama dan penyakit melalui cara kerja yang unik, yaitu dapat melalui perpaduan beberapa cara atau secara tungal. Cara kerja sangan spesifik yaitu: merusak perkembangan, telur,larva dan pupa, penolak makan, menghambat reproduksi serangga betina hama, mengusirserangga dan menghambat penggantian kulit serangga (Solikin, 2011).

\section{KESIMPULAN DAN SARAN}

\section{Kesimpulan}

Ekstrak babadotan bersifat sebagai insektisida botanis terhadap larva instar IV S. litura. Se- makin tinggi konsentrasi ekstrak babadotan yang diberikan maka ekstrak babadotan semakin tinggi tingkat mortalitas larva uji

\section{Saran}

Dengan adanya hasil penelitian ini, diharapkan dapat memberikan informasi bagi semua pihak bahwa tanaman babadotan dapatb digunakan sebagai insektisida yang ramah lingkungan.

Diharapkan penelitian ekstrak babadotan ini dapat dilanjutkan untuk diujikan langsung ke tanaman yang terserang serangga.

Diharapkan adanya penelitian lebih anjut mengenai pengaruh ekstrak babadotan terhadap jenis serangga lainnya. 


\section{DAFTAR PUSTAKA}

Ardiansyah. 2007. Hama dan Penyakit Tanaman Perkebunan. Penerbit Kanisius Yogyakarta

Dinata,A. 2007. Basmi Lalat dengan Jeruk Nipis http://www/litbang.depkes. go.id/lokaciamis/artikel/lalat-arda.htm.

Harahap, I. 2005. Seri PHT Hama Palawija. Penebar Swadaya: Jakarta.

Jumar. 1997. Entomologi Pertanian. Penerbit Rineka Cipta : Banjar Baru.

Kardinan, A. 2001. Pestisida Nabati Ramuan dan Aplikasi Cetakan ke-3. Penebar Swadaya: Jakarta.

Noviza. 2002. Membuat dan Memanfaatkan Pestisida Ramah Lingkungan. Agromedia Pustaka: Jakarta
Pandit, I. 2006. Resiko Pestisida Nabati. http://www.balopost.co.id/ balipostcetak 2006/4/5/02.htm.

Pracaya. 2005. Hama dan Penyakit Tanaman. Penebar Swadaya: Jakarta.

Samsudin, H. 2008. Pengendalian Hama Dengan Insektisida Botani. http://www.pertanian sehat.or.id/index.php?pilih=news\&mod=ye s\&aksi=lihat\&id=20.

Soemadi, W. 2003. Pengendalian Hama Tanaman Pangan. CV Aneka: Bogor.

Sudarmo, S. 2000. Pengendalian Serangga Hama. Kanisius: Yogyakarta. 
